\title{
Normative values for a new water-perfused high resolution manometry system
}

\author{
Rogério Mariotto Bitetti da SILVA, Fernando A M HERBELLA and Daniel GUALBERTO
}

Received 22/2/2018

Accepted 3/4/2018

\begin{abstract}
Background - Esophageal manometry is the most reliable method to evaluate esophageal motility. High resolution manometry (HRM) provides topographic contour colored plots (Clouse Plots) with simultaneous analysis from the pharynx to the stomach. Both solid state and water-perfused systems are available. Objective - This study aims to determinate the normative data for a new water-perfused HRM. Methods - HRM was made in 32 healthy volunteers after 8 hours fasting. HRM system used consisted of a 24-channel water-perfused catheter (Multiplex, Alacer Biomedica, São Paulo, Brazil). The reusable catheter is made of polyvinyl chloride (PVC) with $4.7 \mathrm{~mm}$ of diameter. Side holes connected to pressure transducers are spaced $2 \mathrm{~cm}$ for the analysis from the pharynx to the lower esophageal sphincter (LES). Holes are spaced $5 \mathrm{~mm}$ and $120^{\circ}$ in a spiral disposition in the LES area. The sensors encompass $34 \mathrm{~cm}$ in total. Upper esophageal sphincter (UES) parameters studied were basal and relaxation pressures. Esophageal body parameters were distal contractile integral (DCI), distal latency (DL) and break. LES parameters studied were basal pressure, integrated residual pressure (IRP), total and abdominal length. Variables are expressed as mean \pm standard deviation, median (interquartile range) and percentiles 5-95th. Results - All volunteers (17 males, aged 22-62 years) completed the study and tolerated the HRM procedure well. Percentiles 5-95th range were calculated: Upper Esophageal Sphincter (UES) basal pressure 16.7-184.37 (mmHg), DL: 6.2-9.1 (s), DCI: 82.72-3836.61 (mmHg.s.cm), break: $<7.19(\mathrm{~cm})$, LES basal pressure: 4.89-37.16 (mmHg), IRP: 0.55-15.45 (mmHg). Conclusion - The performance and normative values obtained for this low-cost water-perfused HRM seems to be adequate for clinical use.
\end{abstract}

HEADINGS - Esophageal motility disorders. Manometry, trends. Low cost technology.

\section{INTRODUCTION}

Esophageal Manometry is the most reliable method to evaluate esophageal motility ${ }^{(1)}$. It was introduced in medical practice by the 1940ies with simple systems based on water-filled balloons that evolved to the current high resolution systems ${ }^{(2)}$. High resolution manometry (HRM) provides topographic contour colored plots (Clouse Plots) with simultaneous analysis from the pharynx to the stomach making the test faster, more comfortable, less susceptible to inter-observer variability, easier to interpret and compensation of movements' $\operatorname{artefacts}^{(3)}$.

HRM is based on closely distanced and multiple sensors organized along the probe that varies in number according to different systems ${ }^{(4,5)}$. Both solid state and water-perfused systems are available. This myriad of different configurations demands the determination of reference values according to each technology as has been demonstrated by different studies ${ }^{(2)}$.

This study aims to determinate the normative data for a new 24 channel water-perfused HRM.

\section{METHODS}

\section{Subjects}

We studied 32 (17 males, mean age 34 years range 21-62, mean body mass index $24 \mathrm{Kg} / \mathrm{m}^{2}$ range 21-32) healthy volunteers. Individuals with upper digestive symptoms in the past 6 months; on drugs that could affect esophageal motility; systemic diseases that can modify esophageal motility; upper digestive tract surgery; or unable to understand the consent form were exclude form the study.

\section{High resolution manometry}

All individuals underwent a HRM after 8 hours fasting. The test was performed in left lateral decubitus. After a period for adaptation to the catheter, individuals were instructed to prevent swallowing for a period of 30 seconds in order to acquire resting parameters and subsequently 10 swallows of 5 -mL every 30 seconds were offered to acquire dynamic parameters.

HRM system used consisted of a 24-channel water-perfused catheter (Multiplex, Alacer Biomedica, São Paulo, Brazil). The reusable catheter is made of polyvinyl chloride (PVC) with 4.7 $\mathrm{mm}$ of diameter. Side holes connected to pressure transducers are spaced $2 \mathrm{~cm}$ for the analysis from the pharynx to the lower esophageal sphincter (LES). Holes are spaced $5 \mathrm{~mm}$ and $120^{\circ}$ in a spiral disposition in the LES area. The sensors encompass $34 \mathrm{~cm}$ in total (FIGURE 1). Perfusion is managed by an original patented controlled peristaltic pump.

\section{Manometric parameters}

Manometric parameters evaluated were those standardized by the International High Resolution Manometry Working Group in 2015, the Chicago classification 3.0 $0^{(6)}$. Data was obtained based on automated analysis by the dedicated software (Esofagica v.1492. Alacer Biomedica, São Paulo, Brazil). 


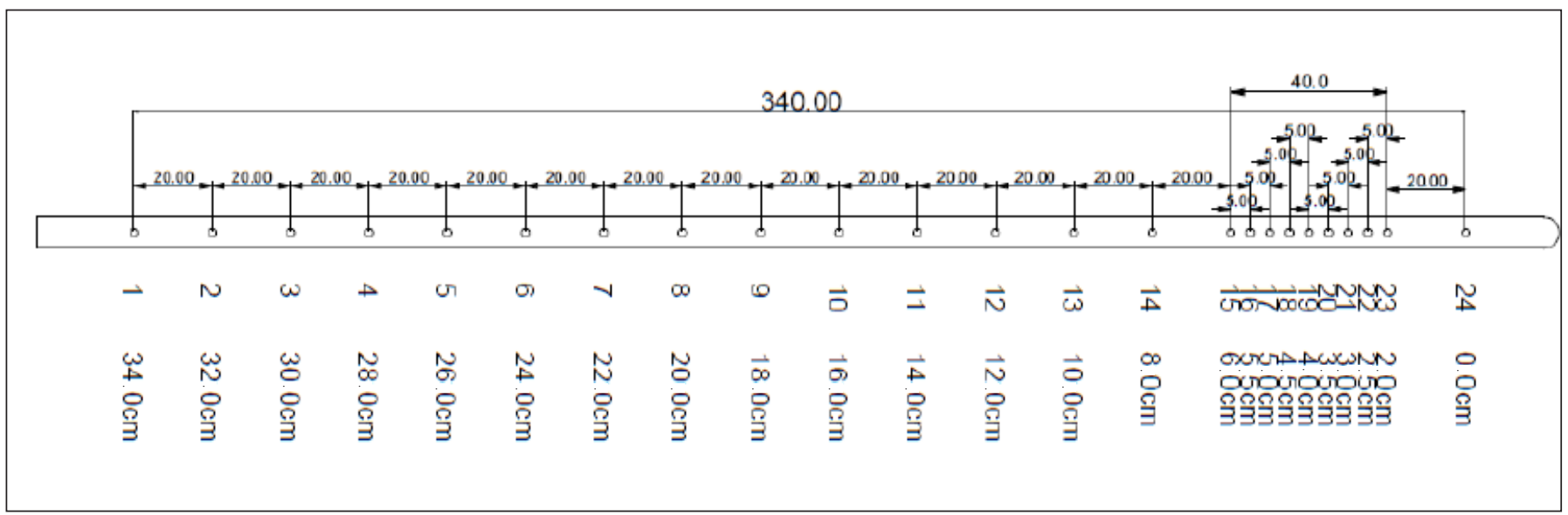

FIGURE 1. High resolution manometry water-perfused 24-sensors catheter.

Upper esophageal sphincter (UES) parameters studied were basal and relaxation pressures (FIGURE 2). Esophageal body parameters were distal contractile integral (DCI), distal latency (DL) and break (FIGURE 3). Lower esophageal sphincter (LES) parameters studied were basal pressure, integrated residual pressure (IRP), total and abdominal length (FIGURE 4).

\section{Stastistical analysis}

Variables are expressed as mean \pm standard deviation, median (interquartile range) and percentiles 5-95th.

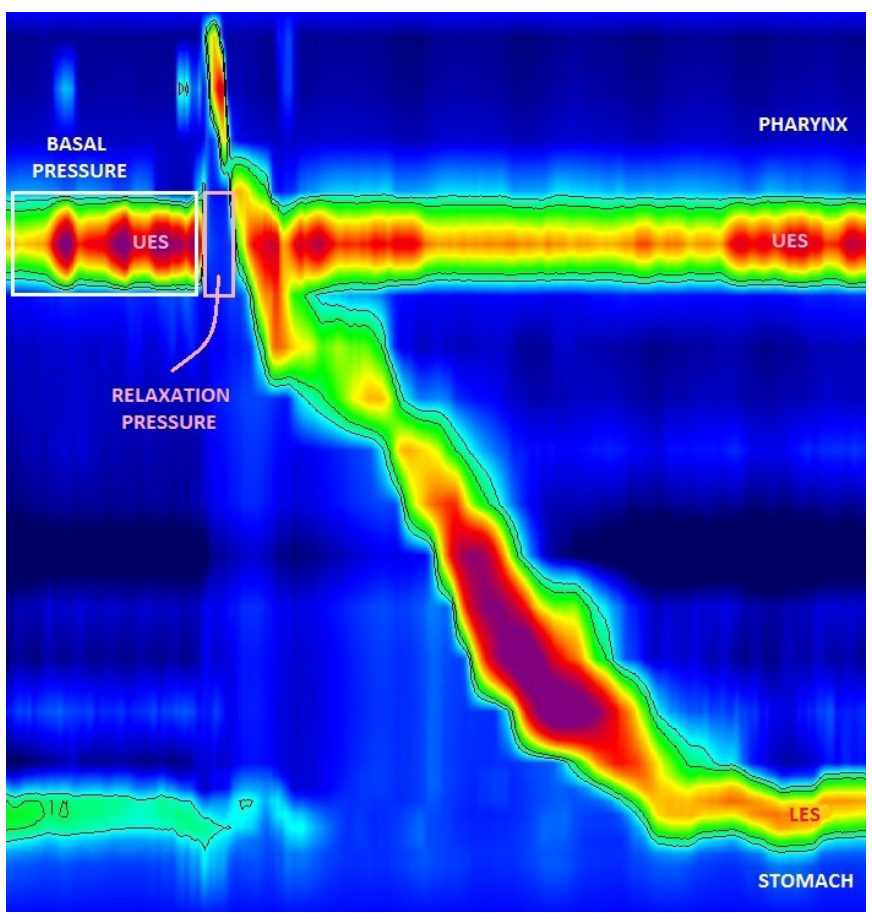

FIGURE 2. Manometric parameters for the upper esophageal sphincter (UES). UES basal pressure is determined by the higher pressure within the user determined limits of the sphincter. The measurement is obtained just in one instance in the resting status. Relaxation pressure is determined by the nadir pressure lesser pressure within the user determined limits of the sphincter during swallows. The measurements are performed for all swallows and averaged.

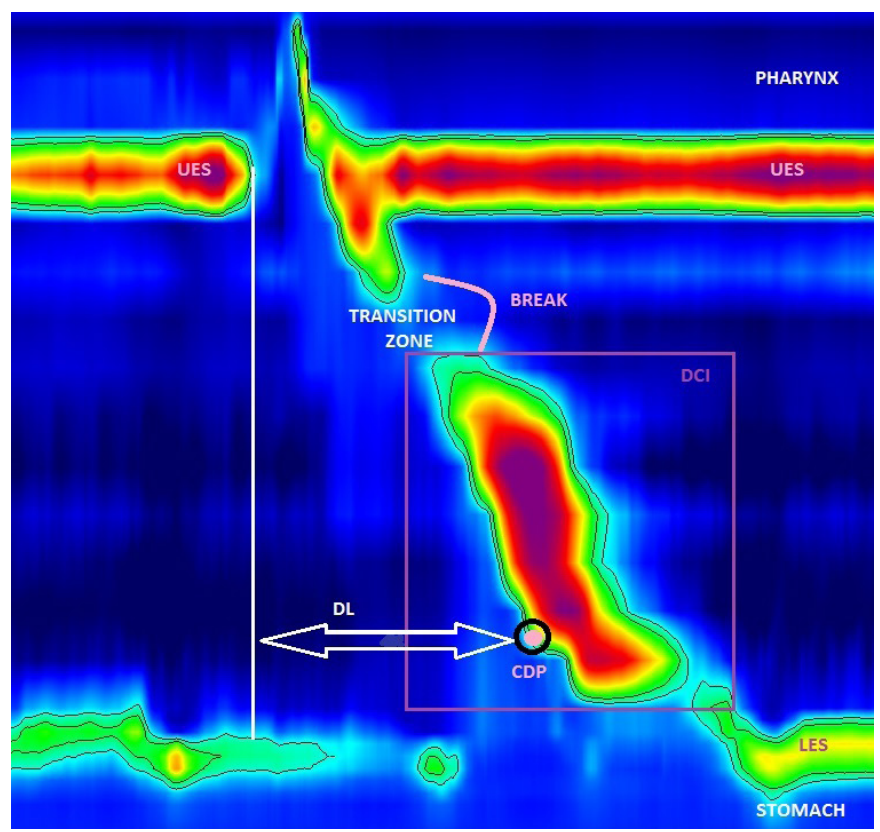

FIGURE 3. Manometric parameters for the esophageal body. Distal latency (DL) is measured the time between the beginning of swallow (upper esophageal sphincter relaxation) to the contractile desaceleration point (CDP) manually determined by the user. CDI is automatically calculated within the area of the user-determined peristaltic wave as the product of the mean amplitude of contraction in the distal esophagus $(\mathrm{mmHg}$ ) times the duration of contraction (seconds), times the length of the distal esophageal segment $(\mathrm{cm})$ exceeding $20 \mathrm{mmHg}$ for the region spanning from the transition zone to the proximal aspect of the lower esophageal sphincter (LES). Break is calculated by the gap between zones of pressures $>20 \mathrm{mmHg}$ within the user-determined defined zone.

\section{Ethics}

The project was approved by local ethics committee and all participants signed a consent form before entering the study.

The authors are responsible for the study, no professional or ghost writer was hired.

The corresponding author is a consultant for the HRM manufacturer. 


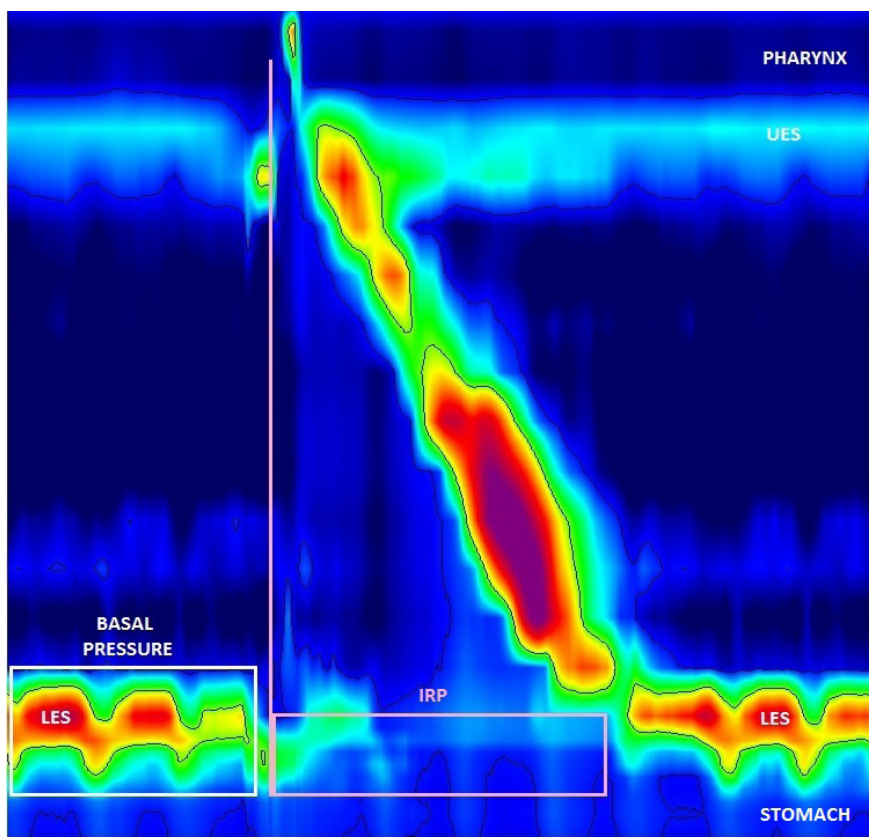

FIGURE 4. Manometric parameters for the lower esophageal sphincter (LES). LES basal pressure is determined by the higher pressure within the user determined limits of the sphincter. The measurement is obtained just in one instance in the resting status. Relaxation pressure is determined by the integrated relaxation pressure (IRP) within the user determined limits of the sphincter during swallows. The measurements are performed for all swallows and a median calculated.

\section{RESULTS}

Manometric parameters are shown in TABLE 1.

\section{DISCUSSION}

HRM has proven advantages over conventional manometry ${ }^{(7)}$. Solid state HRM systems have a faster response to changes in pressure and circumferential disposition of sensors ${ }^{(2)}$ but a higher cost. These characteristics allow better evaluation of striated muscles ${ }^{(8)}$ and sphincters relaxation ${ }^{(9)}$. Water-perfused HRM systems are cheaper and may be adequate for routine clinical practice ${ }^{(5,10-12)}$. It is worth remembering that most of the conventional manometry equipment used a water-perfused system ${ }^{(13)}$. The number of sensors; however, may be limited by the diameter of water-perfused catheters. Most current systems adopted a HRM sensor disposition -i.e. circumferential sensors closely spaced - limited to the LES area ${ }^{(2)}$. The asymmetry of the LES imposes a circumferential disposition in this zone forcing the use of most of the sensors available in this part of the catheter.

The system tested in this study employs a spiral disposition of the sensors. This original configuration was developed to allow a radial evaluation of the LES and save sensors to be used for the esophageal body and UES. Other studies that defined normative values employed only two different commercial systems that use 22 or 36 sensors disposed every $1 \mathrm{~cm}$ in the areas measuring the LES, and every $2 \mathrm{~cm}$ in the areas measuring the esophageal body, similar to our equipment, but with a radial distribution of distal sensors $^{(5,10,12)}$

The colorful intuitive panoramic view of the esophageal motility provided by HRM stimulated the human eyes to distinguish subtle parameters unknown or uncomprehend so far ${ }^{(14)}$ culminating with the Chicago Classification that defined the current parameters used for the evaluation of esophageal motility ${ }^{(6)}$. UES was neglected on the 3.0 version of the Chicago classification with a promised inclusion on the next version ${ }^{(6)}$. In our study, UES was detected and analyzed in all cases. Our system performed visually similar to solid-state equipment with a centrifuge decrease of pressure but well-defined borders. The limitation of the non-

TABLE 1. Esophageal parameters in healthy volunteers $(n=32)$.

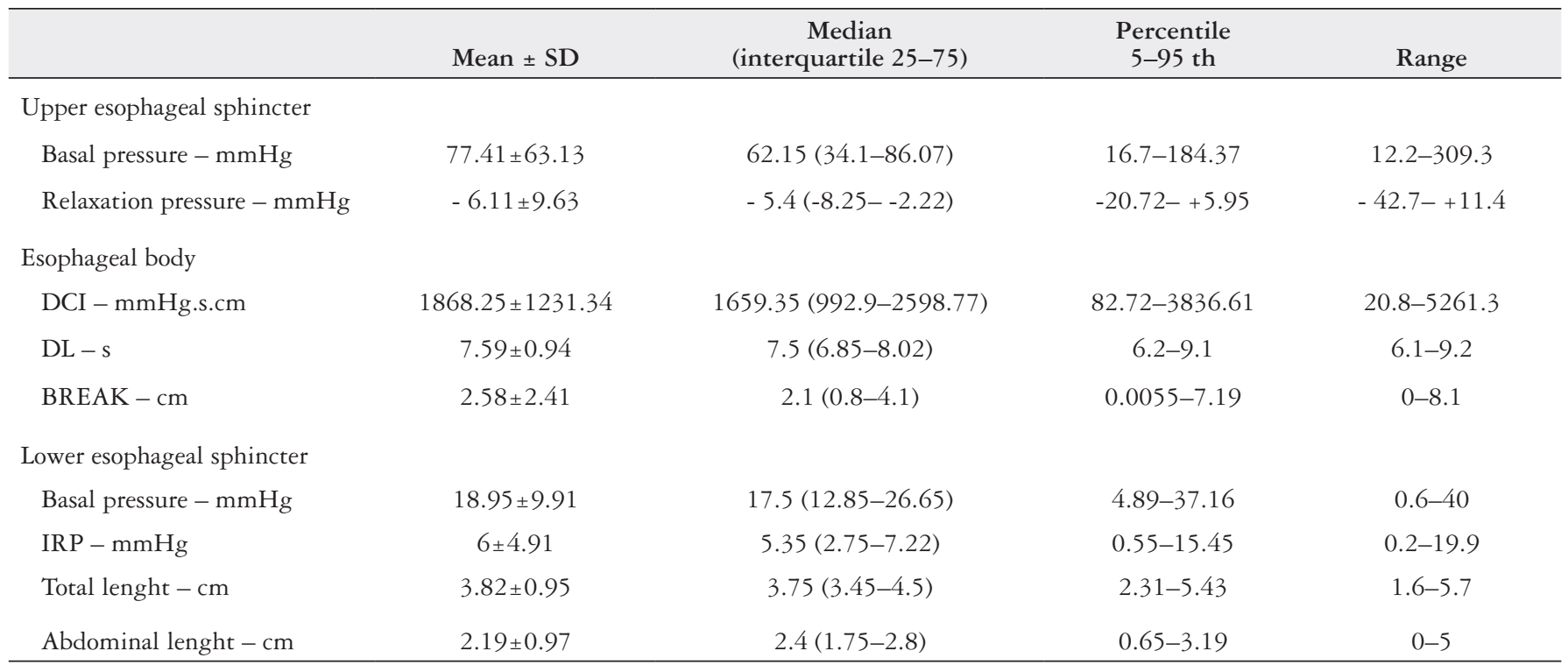

DCI - distal contractile integral. DL - distal latency. IRP - integrated residual pressure. 
circumferential analysis in this area is yet to be proven, as the UES pressures are also asymmetrical radially ${ }^{(15)}$. Detailed visualization of the structures of the pharynx was not possible as compared to solid state systems ${ }^{(8)}$.

Esophageal body contractions are symmetrical radially. The lack of radial sensors in our low-cost system for the esophageal body area does not preclude a detailed analysis of this segment. Sensors are; however, $2 \mathrm{~cm}$ spaced, not $1 \mathrm{~cm}$ as usual in solid-state systems. Segmental defects of peristalsis (fragmented peristalsis) are rare in routine clinical practice and long peristaltic gap in the transition zone (break) is considered pathologic if over $5 \mathrm{~cm}^{(3)}$, thus amenable to detection by the tested system. The determination of the contractile deceleration point (CDP) - necessary to define the $\mathrm{DL}$ - may have a $\pm 1 \mathrm{~cm}$ error, what we believe is also not clinically significant. Interestingly, all water-perfused systems have similar normal values for DL (TABLE 2) and higher than the solid-state systems $^{(2)}$. This may be explained by the retarded response sensors due to the delay in pressure transmission along the water-systems as compared to solid-state transducers.

A reliable assessment of the relaxation of the LES is probably the best contribution of $\mathrm{HRM}^{(7,16)}$. The concentration of sensors provided by the technology compensates for motion artifacts avoiding erroneous interpretation of LES pseudo-relaxation ${ }^{(17)}$ and allows a more sophisticated parameter to evaluate relaxation in opposition to nadir pressure only, the $\operatorname{IRP}^{(16)}$. Water-perfused systems present a variable number of sensors distally in the probe but closely space to provide this advantage of HRM. The system evaluated in the current study differs from other water-perfused equipment due to a spiral disposition of the sensors. Our results of the LES are within the range of values found for different waterperfused systems.

This study evaluated a small number of volunteers due to the difficult in recruiting healthy individuals to an uncomfortable test. Also, normative values were not validated in patients yet. A study is in progress and it will include patients with well-established achalasia and other LES disorders to demonstrate that the threshold found for IRP (a sensitive parameter to be evaluated in new systems) is clinically valuable. Despite these limitations, the performance and normative values obtained for this low-cost water-perfused HRM seems to be adequate for clinical use.

\section{ACKNOWLEDGMENTS}

We are indebted to Ms. Vanessa Tuxen for her invaluable assistance with the esophageal tests.

\section{Authors' contribution}

All authors listed on the manuscript have contributed sufficiently to the project to be included as authors and approved the manuscript.

TABLE 2. Normative values for water-perfused high resolution esophageal manometry systems.

\begin{tabular}{|c|c|c|c|c|c|}
\hline & Current study & Tseng et al. & Kessing et al. & Burgos Santamaria et al. & Capovilla et al. \\
\hline Number of volunteers & 32 & 66 & 50 & 16 & 20 \\
\hline Catheter (number of sensors) & 24 & 22 & 36 & 22 & 24 \\
\hline $\mathrm{DL}-\mathrm{s}$ & $>6.2$ & $>6.2$ & $>6.2$ & $>6.1$ & $>7.0$ \\
\hline LES basal pressure $-\mathrm{mmHg}$ & $5-37$ & $8.7-46.5$ & $<18.8$ & $<54$ & NA \\
\hline break $-\mathrm{cm}$ & $>7 \mathrm{~cm}$ & $0-13.4$ & NA & NA & NA \\
\hline
\end{tabular}

LES: lower esophageal sphincter; DCI: distal contractile integral; DL: distal latency; IRP: integrated residual pressure.

Silva RMB, Herbella FAM, Gualberto D. Valores de normalidade de um novo sistema de manometria de alta resolução por perfusão de água. Arq Gastroenterol. 2018. Ahead of print.

RESUMO - Contexto - Manometria esofágica é o exame mais confiável para avaliar motilidade esofágica. Manometria esofágica de alta resolução (MAER) apresenta um gráfico dinâmico e colorido (Clouse plots) com análise simultânea da faringe ao estomago. Dois tipos de manometria estão disponíveis: estado sólido e por perfusão de água. Objetivo - Determinar os valores de normalidade de um novo sistema de manometria de alta resolução. Métodos - MAER foi realizada em 32 voluntários saudáveis após jejum de oito horas. O sistema utilizado é de perfusão de água com 24 sensores (Multiplex, Alacer Biomedica, São Paulo, Brasil). O catéter permanente é feito de cloreto de polivinil (PVC) com 4,7 mm de diâmetro. Os orifícios laterais para conexão com os transdutores de pressão são espaçados de $2 \mathrm{~cm}$ para análise da faringe ao esfíncter esofagiano inferior (EEI) e são esparçados em $5 \mathrm{~mm}$ em forma espiralada com $120^{\circ}$ entre orificios. Os sensores no total englobam $34 \mathrm{~cm}$. Para o esfíncter esofágico superior (EES), os parâmetros estudados foram às pressões basal e de relaxamento. Os parâmetros do corpo esofágico foram: integral de contratilidade distal (DCI), latência distal (DL) e quebra. Os parâmetros do EEI inferior foram pressões basal e de relaxamento e pressão de relaxamento integrada (IRP). As variáveis foram expressas em medias \pm desvio padrão, medianas (variação de interquartis) e percentis 5-95. Resultados - Todos os voluntários (17 homens, com idade variando entre 22-62 anos) terminaram e toleraram o exame. A variação dos percentis 5-95 foi calculada: pressão basal do esfíncter esofágico superior (EES) foi 16,7-184,37 (mmHg), DL: 6,2-9,1 (s), DCI: 82,72-3836,61 (mmHg.s.cm), quebra: <7,19 (cm), pressão basal do EEI: 4,89-37,16 (mmHg), IRP: 0,55-15,45 (mmHg). Conclusão - A realização dos testes e os valores de normalidade determinados por este estudo parecem ser adequadas para a prática clínica.

DESCRITORES - Transtornos da motilidade esofágica. Manometria, tendências. Tecnologia de baixo custo. 


\section{REFERENCES}

1. Jobe BA, Richter JE, Hoppo T, Peters JH, Bell R, Dengler WC, et al. Preoperative diagnostic workup before antireflux surgery: an evidence and experience based consensus of the Esophageal Diagnostic Advisory Panel. J Am Coll Surg 2013;217:586-97.

2. Herregods TV, Roman S, Kahrilas PJ, Smout AJ, Bredenoord AJ. Normative values in esophageal high-resolution manometry. Neurogastroenterol Motil 2015;27:175-87.

3. Schlottmann F, Herbella FA, Patti MG. Understanding the Chicago Classification: From Tracings to Patients. J Neurogastroenterol Motil. 2017;234:487-94.

4. Smout AJ. Manometry of the gastrointestinal tract: toy or tool? Scand J Gastroenterol Suppl. 2001;234:22-8.

5. Kessing BF, Weijenborg PW, Smout AJ, Hillenius S, Bredenoord AJ. Water-perfused esophageal high-resolution manometry: normal values and validation. Am J Physiol Gastrointest Liver Physiol. 2014;306:G491-5.

6. Kahrilas PJ, Bredenoord AJ, Fox M, Gyawali CP, Roman S, Smout AJ, et al. The Chicago Classification of esophageal motility disorders, v3.0. Neurogastroenterol Motil. 2015;27:160-74.

7. Salvador R, Dubecz A, Polomsky M, Gellerson O, Jones CE, Raymond DP, et al. A New Era in Esophageal Diagnostics: The Image-Based Paradigm of High-Resolution Manometry. J Am Coll Surg. 2009;208:1035-44.

8. Silva LC, Herbella FA, Neves LR, Vicentine FP, Neto SP, Patti MG. Anatomophysiology of the Pharyngo-Upper Esophageal Area in Light of High-Resolution Manometry. J Gastrointest Surg. 2013:17:2033-8.

9. Gehwolf P, Hinder RA, DeVault KR, Edlinger M, Wykypiel HF, Klingler PJ. Significant pressure differences between solid-state and water-perfused systems in lower esophageal sphincter measurement. Surg Endosc. 2015:2912:3565-9.
10. Burgos-Santamaría D, Marinero A, Chavarría-Herbozo CM, Pérez-Fernández T, López-Salazar TR, Santander C. Normal values for waterperfused esophageal high-resolution manometry. Rev Esp Enferm Dig. 2015;107:354-8.

11. Capovilla, G, Savarino, E, Costantini, M, Nicoletti, L, Zaninotto, G, Salvador, $\mathrm{R}$. Inter-rater and interdevice agreement for the diagnosis of primary esophageal motility disorders based on Chicago Classification between SolidState and Water-Perfused HRM System- A Prospective, Randomized, Double Blind, Crossover Study. Gastroenterology. 2014;146:S-681

12. Tseng PH, Wong RKM, Wu JF, Chen CC, Tu CH, Lee YC. Normative values and factors affecting water-perfused esophageal high-resolution impedance manometry for a Chinese population. Neurogastroenterol Motil. 2018;30:e13265.

13. Sweet MP, Herbella FAM, Leard L, Hoopes C, Golden J, Hays S, et al. The prevalence of distal and proximal gastroesophageal reflux in patients awaiting lung transplantation. Ann Surg. 2006;244:491-7.

14. Herbella FA, Patti MG. Can high resolution manometry parameters for achalasia be obtained by conventional manometry?. World J Gastrointest Pathophysiol 2015;6:58-61.

15. Meyer JP, Jones CA, Walczak CC, McCulloch TM. Three-dimensional manometry of the upper esophageal sphincter in swallowing and nonswallowing tasks Laryngoscope. 2016;126:2539-45.

16. Lafraia FM., Herbella FAM., Kalluf JR., Patti MG. A pictorial presentation of esophageal high resolution manometry current parameters. Arq Bras Cir Dig. 2017:30:69-71

17. Katz PO, Richter JE, Cowan R, Castell DO. Apparent Complete Lower Esophageal Sphincter Relaxation in Achalasia. Gastroenterology. 1986;90:978-83. 